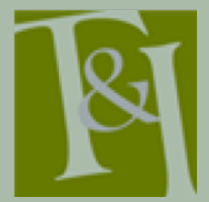

The International Journal for Translation \& Interpreting Research trans-int.org

\section{Norms and gender in simultaneous interpreting: a study of connective markers}

\author{
Cédric Magnifico \\ Ghent University, Belgium \\ Cedric.Magnifico@UGent.be
}

\section{Bart Defrancq}

Ghent University, Belgium

Bart.Defrancq@UGent.be

DOI : 10.12807/ti.112201.2020.a01

\begin{abstract}
This paper focuses on a possible gender-based approach towards norms in simultaneous interpreting by analysing the use of connective markers by male and female interpreters to reveal patterns of interpreters' handling of translational norms. Drawing on the 2008 subcorpus of EPICG with French source texts and their English and Dutch interpretations, the present study checks whether male and female interpreters translate, omit or add connective markers in the same way. The results are then tested against other parameters which might have an influence such as language, speech delivery rate or the gender of the speaker. It appears that the interpreter's gender does not affect the use of connective markers. As for the other parameters under study, it seems that only speech delivery rate significantly impacts the interpreters' performances, especially when it comes to the omission of connective markers.
\end{abstract}

Keywords: Interpreting studies; norms; gender studies

\section{Introduction}

This paper is part of a project on gender-based differences in simultaneous interpreting and examines possible gender-based approaches towards norms. Research on norms in interpreting has only recently seen an increase of interest and is traditionally conducted based on the framework of translational norms (Schjoldager, 1995; Shlesinger, 1989; Toury, 1980). Although interpreters are expected to comply with interpreting norms (Harris, 1990), such as completeness, accuracy, first-person rendition, etc., it seems that specific features of the interpreting process sometimes force interpreters to breach them. Cognitive load in particular is blamed for errors and omissions, i.e. incomplete and inaccurate renderings of source texts (Gile, 1995).

Focusing on courtroom interpreting, Hale (2004) and Mason (2008) notice for instance that interpreters tend to omit certain elements, such as pragmatic markers, when they are faced with cognitive overload. More recent studies adduce that these omissions and shifts from the source speech could be part of the interpreter's strategy in specific settings (Diriker, 2004; Jansen 1992; Monacelli, 2009; Wadensjö 1992).

With our study, we intend to contribute to the study of norms in the field of interpreting. Most scholars (Barik, 1971; Lederer, 1981; Seleskovitch 1975) focusing on interpreting norms adopt a textual approach and compare source texts and target texts. This approach allows them to identify the errors, omissions and infelicities (Gile, 2009) made by the interpreter, which can lead 
to an inadequate or unacceptable interpretation, as defined in Toury's framework of translational norms (Toury, 1980). However, most of these studies are conducted on a small scale. Only a corpus-based study carried out on a larger scale can reveal patterns of interpreters' handling of translational norms. This study adopts such an approach.

In this context, the handling of discourse markers can yield interesting results. Discourse markers are often considered vulnerable and non-essential in interpreting (Barik, 1971; Hale, 2004; Shlesinger, 1995). A more recent study conducted on connective markers (Defrancq et al., 2015) reveals that interpreters drastically reshape the discourse structure by not only omitting connective items but also by adding them. Considered from a norm perspective, these additions and omissions could be seen as a norm infringement or an interpreting strategy (Schjoldager, 1995).

The present study also intends to contribute to gender studies. Gender differences in interpreting are not well researched, although the profession is highly gender-biased: women outnumber men by far in the profession (Angelelli, 2004). Early research in court room interpreting suggests that pragmatic items seem to be handled differently by male and female interpreters (Mason, 2008). More recently, corpus-based research conducted on interpersonal relationships in simultaneous interpreting (Magnifico \& Defrancq, 2016, 2017, 2019) ascertains that gender is a determining factor in the handling of impoliteness and hedges by interpreters working at the European Parliament. As hedges and discourse markers are both pragmatic items, the study of the latter could also bring to light gendered approaches. We choose to focus on a particular brand of discourse markers, i.e. connective markers, because they constitute one of the most fruitfully studied areas in corpus-based Translation Studies and have sparked interesting debates on translation universals which will feed into our reflection (Becher, 2010; Defrancq et al., 2015; Mauranen, 2000; Olohan \& Baker, 2000; Puurtinen, 2004; Saldanha, 2008; Vandepitte et al., 2013).

In this paper, we will investigate whether male and female interpreters have a different approach to translational norms in interpreting, focusing on a classical dimension of norms, i.e. accuracy. Considering the aforementioned arguments, we hypothesize that male and female interpreters do not translate and omit connective markers the same way. As the use of connective markers by interpreters has already been analysed in Defrancq et al. (2015), we will essentially follow the same research design as the one used there, comparing female and male interpretations at the European Parliament. However, unlike previous work we have carried out on norms in interpreting (Magnifico \& Defrancq, 2019), we will not assume that female and male interpreters face the same working conditions in the European Parliament. We will therefore include more parameters in the study to assess whether gender is a predominant factor or whether other factors can influence the results.

In section 1 of this paper, we will review the literature on norms in interpreting; we will then examine the gender aspect in relation to interpreting norms in section 2 before defining connective markers in section 3 . We will then describe our data and methodology before presenting the results. In section 5 , we will discuss the results before concluding.

\section{Norms in interpreting}

Interpreting norms have only recently gained interest. The first interpreting scholars focusing on norms adopted Toury's framework $(1980,1995)$ and tried to transfer translational norms to interpreting (Harris, 1990; Shlesinger, 1989). According to Toury, translation is a normative activity where translators are faced with a so-called "initial norm", i.e. a choice to apply the norm system of 
the source language or that of the target language. Depending on that choice, they will produce an adequate translation (source norms) or an acceptable translation (target norms). Toury (1995) suggests that translational norms are to be found through two major sources, i.e. textual and extratextual:

(1) textual: the translated texts themselves, for all kinds of norms, as well as analytical inventories of translations (i.e., 'virtual' texts'), for various preliminary norms;

(2) extratextual: semi-theoretical or critical formulations, such as prescriptive 'theories' of translation, statements made by translators, editors, publishers, and other persons involved in or connected with the activity, critical appraisals of individual translations, or the activity of a translator or 'school' for translators, and so forth (Toury, 1995, p. 65)

As we argued in a previous paper focusing on norms in interpreting (Magnifico \& Defrancq, 2019), interpreting norms can also be divided into textual and extratextual norms following Toury's classification (1995). In the first category, we can group scholars studying norms through a textual approach (Barik, 1971; Diriker, 2004; Jansen, 1992; Lederer, 1981; Monacelli, 2009; Schjoldager, 1995; Seleskovitch, 1975; Wadensjö, 1992). These scholars study interpreter translating strategies and behaviour in various settings by analysing the interpreter output. They use textual evidence to investigate the norms interpreters apply or infringe. Taking a textual approach, Barik (1971) for instance examines occurrences where interpreters deviate from the source text. He then classifies these occurrences according to their nature - omissions, additions, and substitutions and errors - and to their seriousness, which he measures through the impact on the meaning. He thereby explores norms through the lens of 'adequacy'. Also adopting a textual approach, Seleskovitch (1975), on the other hand, focuses on another parameter, namely the 'acceptability' of a translation, to ascertain norms in interpreting. She grounds her théorie du sens in a comparative analysis of texts collected from an experiment, stressing that interpreters should not translate word for word but have to deverbalize the sentences to understand the meaning of the source text in order to rephrase it in the target language and thereby produce an 'acceptable' interpretation. Drawing on Seleskovitch's framework, Lederer (1981) also proceeds to a similar analysis in the field of simultaneous interpreting and reaches the same conclusions. With the pragmatic turn in interpreting studies, scholars tend to stress factors that impede the upholding of translation norms; however, the methodological approach based on textual evidence remains pervasive. Jansen (1992) and Wadensjö (1992) approach norms using textual evidence of inaccuracies in interpreting triggered by a propensity to cater for the defendant's needs or to disambiguate their renditions. In the area of simultaneous interpreting, Schjoldager (1995) stresses that translational norms can be superseded by other features of simultaneous interpreting, such as cognitive overload. Also adopting a textual approach, Diriker (2004) notices that interpreters break the norm of the 'honest spokesperson' (Harris 1990), moving away from first-person reference, especially in case of incidents. Monacelli (2009) observes the same reaction when the interpreter's face could be threatened: they do not always translate what is said under certain circumstances.

The second category consists of research adopting an extratextual approach in an attempt to reveal the norms interpreters abide by. Methods used range from gathering information from interpreters, users, or from other actors intervening in the process (Bühler, 1986), identifying the user's expectations which lead interpreters to translate in a particular way (Pöchhacker, 1995), or conducting ethnographic studies (Duflou, 2016). Interpreters' expectations and 
internalized norms are fairly well explored in scholarly work, starting with Bühler (1986), who submitted fifteen criteria affecting the quality of simultaneous interpreting such as voice, sense consistency and logical cohesion to AIIC interpreters, asking them to rank these criteria according to importance. 'Sense consistency with original message' and 'logical cohesion of utterance' were ranked as top priorities by most of the interpreters, while 'native accent' and 'pleasant voice' are at the bottom of the list. In the same vein, Zwischenberger (2009) examines interpreters' self-representation by questioning them about their role and their importance for successful communication. She finds that more than $20 \%$ of interpreters consider themselves as facilitators/enablers of communication, and that the overwhelming majority believe that their work is crucial for successful communication, with female interpreters rating their work as slightly more important than their male colleagues do. On a related note, Pöchhacker \& Zwischenberger (2010) conclude from a survey submitted to interpreters that male interpreters find accuracy and a lively intonation less important than female interpreters. Users' expectations are also explored in a variety of studies as they are found to influence interpreters who are made aware of them (Garzone, 2002). Kopczynski (1994) concludes from a survey submitted to speakers and participants at international conferences that listeners are sensitive to unfinished sentences and incorrect grammar whereas speakers appreciate an exact rendition of their speech. Pöchhacker (1995, p. 36) argues that interpreters adapt their work to the type of meeting as the Skopos in simultaneous interpreting lies at the level of the conference assignment, which means that interpreters could adjust their work to meet the varying needs and expectations of the different user groups. After conducting 201 interviews with speakers and listeners at a conference, Moser $(1995,1996)$ concludes that both speakers and listeners expect interpreters to avoid lagging behind and long pauses, and that terminological accuracy is less important in general meetings than in technical ones. Focusing on quality parameters in SI, Collados et al. (2011) observe that nonverbal parameters, such as monotonous intonation, have a lower impact on users' and interpreters' interpreting quality expectations than verbal parameters, such as cohesion and accurate transmission of sense.

Finally, norms can also be identified through ethnographic study, which also falls into the realm of extratextual approaches. Duflou (2016), for instance, presents rich documentary evidence, interview data and field notes to study the process which beginning interpreters have to go through to become fullyfledged EU interpreters. She observes that newcomers internalize norms through situated learning, i.e. by fully participating in the community of practice within the EU working context. So, she considers that interpreters also adopt norms through practice.

It appears from the literature review that interpreting is a norm-governed activity but that the norms interpreters apply can be contradictory or vary depending on the setting and the interpreter's norm sensitivity. In this study, we will explore a possible gender-mediated aspect of norms in interpreting. We opt for a corpus-based approach as such an approach has proven fruitful in studying gender patterns (Collard, 2019; Magnifico \& Defrancq, 2016, 2017, 2019). We will therefore focus on very specific textual elements, i.e. connective markers, of the source text and on their rendition by male and female interpreters. This method will allow us to reveal patterns on a larger scale and check the statistical significance of potential differences occurring in the work of male and female interpreters. 


\section{Gender and interpreting norms}

According to early approaches to gender (Lakoff, 1975), socialization is a process which divides individuals into two categories, namely men and women, whereby each group learns and internalizes the values, behaviour and roles which are seen as appropriate for that particular group. Lakoff (1975) states that gender differences are then also reflected in language: women hedge more, use more question tags, do not use strong language and feel more uncertain. On a related note, Brody and Hall (1993) observe consistent gender patterns in various emotional processes and argue that the differences in expressing emotions is influenced by the need to fulfil gender roles. These differences can be explained by the socializing process where girls acquire verbal skills earlier than boys and are therefore more skilled to articulate feelings. Boys, on the other hand, grow up avoiding expressing their feelings, namely minimize emotions linked to vulnerability, pain, and fear (Brody \& Hall, 1993). In the same vein, Coates (1993) argues that girls and boys have to acquire a gender identity, namely identifying with the category women or men, during childhood by using the appropriate behaviour and linguistic cues. Coates (1993, p. 1996) also finds that women tend to hedge more than men. In the field of politeness, Holmes (1995) states that women are more polite than men as they are more likely to express positive politeness. Later research in the field (Eckert \& Ginet, 2003) has also investigated gender differences in language, which the authors also explain by the difference in socializing process. Nevertheless, other studies in the field of gender differences have challenged the male - female dichotomy. Bergvall et al. $(1996,2011)$ argue that men and women should not be viewed as mutually exclusive categories but more as a continuum. Moreover, the findings about members of one group should not be oversimplified and stereotyped to be applied to all individuals of that particular group. On a related note, Mills (2003) also states that gender is a more complex feature and that other characteristics - such as education, sexual orientation or race - should be taken into account when examining gender differences. In the field of emotional intelligence, it also appears that gender differences are controversial and are found or not depending on the assessment tool (Sánchez-Núñez et al., 2008).

In the field of spontaneous language, the literature on gender thus is profuse, ranging from studies on gender construction and negotiation through discourse to gender identity, floor management and power strategies (Bergvall et al 1996; Bergvall et al. 2011). In the present paper, we will approach gender through the normative aspect, focusing on men and women's linguistic norm sensitivity. Reviewing the research conducted on this aspect, it appears from the early research that women are found to be more norm-compliant than men: they use the standard language variety more often than men (Labov, 1966), while men are found to prefer less prestigious varieties (Trudgill, 1972). However, more recent research reveals that the relationship between gender and linguistic norms is more complex and multilayered. Labov (2001) notices a gender paradox: women lead linguistic change, i.e. adopt new language varieties faster than men, but at the same time they also tend to use more standard varieties than men. Linguistic innovation is evidently associated with a breach of linguistic norms. In the same vein, Eckert and McConnell-Ginet (2003) find that linguistic usage can mark a social category, and that the use of standard grammar can be due to other parameters such as obedience. In this regard, the use of nonstandard grammar- which men are found to use more than women - at school can be considered as rebellious.

In the field of interpreting envisaged as a specific type of language production, different gender perspectives on norms have been observed. Taking an extratextual approach, $\mathrm{Ng}$ (1992) finds that women attach more importance to correct grammatical structures and social relationships' indicators in student interpreters' renditions, whereas men are more concerned with lexicon and 
overall fluency. Moser (1996) observes that women find terminological accuracy more important than men.

Adopting a textual approach to courtroom interpreting, Mason (2008) examines additions and omissions in interpreters' renditions. While she concludes that men and women make similar numbers of errors, especially during long interpreting turns, she also finds evidence for gender patterns in the type of omissions and additions. Male interpreters tend to omit the discourse marker 'well' and politeness markers whereas women are prone to omit deference items and add more politeness markers. Mason (2008, p. 92) argues that these differences could be explained through the socializing process men and women go through.

Corpus-based research on simultaneous interpreting at the European Parliament (Magnifico \& Defrancq, 2016, 2017, 2019) shows striking gender differences: with regard to interpersonal features female interpreters, when faced with impoliteness, are found to translate more face-threatening acts without mitigation than do male interpreters (Magnifico \& Defrancq, 2016). In a related study, on the other hand, female interpreters are also found to use significantly more hedges, i.e. linguistic items -downtoning the strength of an utterance, than their male colleagues (Magnifico \& Defrancq, 2017). Considered through a normative lens, the results yielded in the handling of impoliteness and hedges could be interpreted as norm breach, as the interpreters move away from the norm of the 'honest spokesperson' (Harris, 1990). Finally, Magnifico and Defrancq (2019) focus on self-repairs as textual elements reflecting the interpreter's norm compliance directly rather than through the normative lens of the researcher. This particular approach of norms revealed that women tend to use more self-repairs in their interpretations than male interpreters.

Reviewing the literature on gender differences, there is general awareness that more traditional approaches, dividing men and women into two groups according to their sex, have come under fire: new approaches underline the importance of other factors influencing the possible differences observed as well as the importance of in-group differences. In the present paper, however, we will classify the interpreters into two groups - male and female - based on their voice, thereby adopting a more traditional approach. We will do so for comparison's sake: the few studies conducted on gender differences in interpreting which yielded gender-based results (Collard, 2019; Magnifico \& Defrancq, 2016, 2017, 2019; Mason, 2008) also approach gender through a traditional lens. Considering the gender differences observed by Mason (2008), we believe that a more in-depth study of connective markers could yield interesting results.

\section{Connective markers}

Connectives markers are traditionally considered among the first elements to be omitted by interpreters. Hale (2004) reports that courtroom interpreters tend to omit them because they are "superfluous to the message". Mason (2008) notices that interpreters omit them when faced with cognitive overload. She further adds that a longer turn length has a negative effect on the interpreter's ability to perform his/her work, leading to more omissions at turn lengths of 13 words or more. However, turn length and turn management may not have the same impact in simultaneous interpreting: simultaneous interpreters are used to interpret long turns as their main activity is interpreting monologues. A recent study on cohesion in the output of simultaneous interpreting (Defrancq et al., 2015) yielded interesting results in this respect: unsurprisingly, omission of connective markers appeared to be more frequent in interpreting than in translation because of the higher cognitive load in interpreting, which leads 
interpreters to prioritize meaning over cohesion (Hale, 2004; Mason, 2008). However, the study conducted by Defrancq et al. (2015) also reveals that interpreters add more connective items than translators, which is unexpected from an interpreter's point of view as it increases the cognitive load. From the point of view of language mediation in general, additions are fairly unremarkable: in translation, for instance, explicitation is a widely discussed phenomenon deemed by some to be a universal feature of translation (Baker, 1993; Dimitrova, 2005). However, Defrancq et al. (2015) show that interpreters add connective items not only to explicitate, but also for other purposes such as buying some time to find a translation, replace items which they have missed or even to hide their uncertainty and save their own face.

Considering all the above, there is reason to believe that connective items can further our insights into norm compliance in male and female interpreters. First of all, connective items are vulnerable and prone to be among the first items omitted by the interpreter in case of cognitive overload (Mason, 2008). From a normative perspective, such an omission can be considered as a norm infringement. Secondly, connective items are pragmatic items just like hedges and the use of hedges has been shown to display gendered patterns. In spontaneous language, Lakoff $(1975)$ and Coates $(1993,1996)$ find that women hedge more than men. This pattern has later been observed in simultaneous interpreting where female interpreters outhedge male interpreters (Magnifico \& Defrancq, 2017).

Drawing on the abovementioned literature, we will focus on the following research question: do male and female interpreters have a different approach in translating connective markers. We will consequently check whether male interpreters translate, omit or add more connective markers than female interpreters, and test the results against other parameters which might influence the results, such as speech delivery rate or the gender of the speaker. We will then conduct a more in-depth analysis by language pair and compare the results with those of the study on hedges in interpreting (Magnifico \& Defrancq, 2017).

\section{Data and methodology}

\subsection{Data}

This study draws on the European Parliament Interpreting Corpus Ghent (EPICG), which is under compilation at Ghent university. The corpus is compiled following the method described in Bernardini et al. (2018): video footages of source speeches delivered during plenary sessions at the European Parliament and their interpretation are transcribed according to the Valibel norms (Bachy et al., 2007), taking into account many oral features such as repetitions, hesitation markers, false starts and so forth. The full corpus currently covers 9 language combinations (French, Dutch, English, and German) and currently comprises ca. 220,000 tokens.

Table 1: number of texts and words in the 2008 subcorpus

\begin{tabular}{|l|l|l|l|l|l|l|}
\hline $\begin{array}{l}\text { Interpreter } \\
\text { gender }\end{array}$ & $\begin{array}{l}\text { \# French } \\
\text { speeches } \\
\text { interpreted } \\
\text { in Dutch }\end{array}$ & $\begin{array}{l}\text { Dutch } \\
\text { interpreter } \\
\text { exposed to } \\
\text { \# words in } \\
\text { French }\end{array}$ & $\begin{array}{l}\text { \# words } \\
\text { produced } \\
\text { by Dutch } \\
\text { interpreter }\end{array}$ & $\begin{array}{l}\text { \# French } \\
\text { speeches } \\
\text { interpreted } \\
\text { in English }\end{array}$ & $\begin{array}{l}\text { English } \\
\text { interpreter } \\
\text { exposed to } \\
\text { \# words in } \\
\text { French }\end{array}$ & $\begin{array}{l}\text { \# words } \\
\text { produced } \\
\text { by English } \\
\text { interpreter }\end{array}$ \\
\hline $\begin{array}{l}\text { Male } \\
\text { interpreters }\end{array}$ & 19 & 14,786 & 11,918 & 16 & 9,817 & 8,258 \\
\hline $\begin{array}{l}\text { Female } \\
\text { Interpreters }\end{array}$ & 20 & 16,687 & 14,484 & 23 & 21,656 & 19,938 \\
\hline Total & $\mathbf{3 9}$ & $\mathbf{3 1 , 4 7 3}$ & $\mathbf{2 6 , 4 0 2}$ & $\mathbf{3 9}$ & $\mathbf{3 1 , 4 7 3}$ & $\mathbf{2 8 , 1 9 6}$ \\
\hline
\end{tabular}


In order to maintain cohesion with previous work, we selected a sub-corpus also used in three of our previous studies (Magnifico \& Defrancq, 2016, 2017, 2019), containing 117,500 words, 39 speeches in French and 39 interpretations, both in Dutch and in English. Of these interpretations, 19 speeches are delivered by men and 20 by women in the French/Dutch language pair, and 16 speeches are delivered by men and 23 by women in the French/English language pair. We included two language pairs - French/Dutch and French/English - to avoid linguistic bias in our results. Table 1 above displays the number of texts and words in the 2008 sub-corpus.

\subsection{Methodology}

The same research design is used as Defrancq et al. (2015). We only selected causal and concessive markers associating clauses with identical grammatical status, excluding in particular subordinating items:

- $\quad$ French: alors, donc, dès lors, c'est pourquoi, c'est pour cela, c'est la raison pour laquelle, mais, pourtant, malgré tout, quand même, tout de même, néanmoins, cependant, toutefois, or;

- English: so, therefore, thus, that is why, as a result, but, however, nevertheless, nonetheless;

- $\quad$ Dutch: dus, daardoor, daarom, dan ook, maar, toch, desalniettemin.

We manually identified all occurrences of these items in the EPICG 2008 sub-corpus, both in the source and in the target texts and then used a concordancer (Wconcord) to make sure that we had not overlooked any item. For each occurrence, we also retrieved the context. Occurrences without a connective function were removed from the data set. For example, we excluded occurrences of the Dutch toch when it was used in a hedging function, i.e. to downtone the strength of a statement and occurrences of intensifying so. We then checked whether the retrieved item could be linked to a similar kind of marker in the corresponding text. This check was done in both directions: from source to target and from target to source. Occurrences were then classified according to seven equivalence relations put forward by Defrancq et al. (2015):

a) The category 'In-group equivalent'. This category includes occurrences where a French item from the abovementioned list corresponds to an item from the Dutch or the English list:

plutôt que d'être livré à leur propre sort / donc il faut élargir l'idée de la famille

(EPICG_01.09.08_evaluationdusystÃ “mededublin_martine.ro ure_I_fr)

[rather than being abandoned to their fate so we need to broaden the idea of the family]

(EPICG_01.09.08_evaluationdusystÃ"mededublin_martine.ro ure_I_en)

This example clearly illustrates the use of 'so' as an equivalent of donc ('thus', 'so'). Both items are part of the abovementioned list and have similar pragmatic features.

b) The category 'Equivalent in source'. This category groups occurrences where a target item from the Dutch or the English list mentioned above corresponds to a source item which is not included in the French list above, but has a causal or concessive meaning. alors on enterre le dossier / alors qu'il y a justement nécessité compte tenu des disparités qu'il y a entre les Etats membres / il 
y a vraiment nécessité / de prendre des positions qui soient claires / dans le respect de la subsidiarité

(EPICG_04_09_2008_protectiondessols_françoisegrossetête I_fr)

[we should basically euh $\mathrm{mm} /$ bury this dossier and forget about it but nevertheless / given the euh major disparities there are between member states we do need to take a very clear position and respect subsidiarity]

(EPICG_04_09_2008_protectiondessols_françoisegrossetête I_en)

In this example, the French 'alors que', which is not included in the French list because it is a subordinating item, has a concessive meaning and is translated by an item of the English list 'but'.

c) The category 'non-equivalent in source'. This category comprises occurrences where a target item from the Dutch or the English list mentioned above corresponds to a source item which is not included in the French list above and does not have the same pragmatic features nous ne sommes pas des archaïques qui voulons condamner ou interdire les fonds alternatifs ou les fonds d' investissement / nous savons simplement / que lorsque des véhicules lorsque des instruments exercent des fonctions aussi stratégiques sur la scène $[\ldots]$

(EPICG 22 0908 hedgefundsprivateequity pervencheberes I_fr)

[we're not just looking to the / past we don't want to ban investment funds but we know / that when financial instruments have such crucial strategic importance on the international scene and financial markets]

(EPICG_22_09_08_hedgefundsprivateequity_pervencheberes I_en)

The French simplement does not have a causal or concessive meaning but seems to be rendered by the concessive connective marker 'but' in English.

d) The category 'Additions'. This category contains occurrences of a target item taken from the English or Dutch list that have no equivalent whatsoever in the French source speech:

voilà la réalité / lorsque vous nous dites / les hedge funds ou les private equity ne sont pas en en cause ce sont les les marchés régulés mais enfin nous n'allons pas faire ici un cours d'économie mais nous savons bien que si les banques ont pu prendre de tels risques / c'est bien parce qu'existaient à leurs côtés des hedge funds et des private equity

[EPICG_22_09_08 hedgefundsprivateequity pervencheberes I_fr]

when we look at hedge funds and private equity and say that we're not really talking about them but the market's regulating them / no / that's we know that if banks want to undertake such risks it's because they've got hedge funds and private equity [EPICG_22_09_08_hedgefundsprivateequity_pervencheberes I_en] 
In Example (d), drawn from the EPICG 2008 sub-corpus, the English connective item 'but' has no equivalent in the French source text. It is untriggered and is therefore considered to be added to the target text.

e) The category 'Equivalent in target' includes occurrences of a source item taken from the French list that correspond to a target item with a causal or concessive meaning that is not included in the Dutch or English list

puissions-nous au moins discuter sérieusement de tout cela avec un esprit ouvert et un grand sens des responsabilités alors la crise aurait au moins servi à quelque chose

[if we could at least discuss seriously all of this with an open mind and a great sense of responsibilities, then the crisis would have at least served a purpose]

(EPICG_24.09.08_situationsystèmefinanciermondial_francisw urtz_I_fr)

moet hier serieus over discussiëren met een open blik als dat gebeurt dan hadden we de cris/ of dan kan de cris/ in ieder geval ergens toe gediend hebben

[have to discuss this seriously with an open gaze if that happens then we had the cris/or can the cris/ in any case served some purpose]

(EPICG_24.09.08_situationsystèmefinanciermondial_francis wurtz_I_nl)

In this example, the French alors which is included in the list has the same meaning as the dan used in Dutch, but which does not appear in our list.

f) The category 'non-equivalent in target'. This category includes occurrences where a source item from the French list corresponds to a target item that does not have a causal or concessive meaning.

ce qui est vrai c'est que si le régime de Dublin / a malgré tout / fait l'objet d'une évaluation positive / il est vrai que ce régime a induit de facto des charges supplémentaires pour certains Etats-membres

[EPICG_01.09.08_évaluation du système de dublin_jacquesba rrot_I_fr]

Dublin has basically met with a favourable assessment but it has meant an additional burden on certain member states [EPICG_01.09.08_évaluation du système de dublin_jacquesba rrot_I_fr]

The French malgré tout is translated by 'basically', which obviously has different pragmatic properties.

g) The category 'Omissions' groups occurrences of a connective marker in the source text that does not have a corresponding item in the target text.

il y a vraiment nécessité / de prendre des positions qui soient claires / dans le respect de la subsidiarité / mais des dispositions claires pour préserver nos sols (EPICG_04_09_2008_protectiondessols_françoisegrossetête I_fr) 
[we do need to take a very clear position and respect subsidiarity with clear ways to protect the soil]

(EPICG_04_09_2008_protectiondessols_françoisegrossetête I_en)

After classifying the different occurrences, we first conducted a chi-square test within each strategy to test for possible gender differences. We then carried out a multinomial regression test to cross the various parameters and determine whether the language, the gender of the speaker, the speech delivery rate, were significant factors. For the speed of delivery, we classified the speeches into three categories: less than 120 words/minute; 120 to 159 words/minute; over 159 words/minute (Gerver, 1969). We finally turned to the strategies used within each language pair and carried out a chi-square test to examine whether there were differences between male and female interpreters in the use of a specific strategy.

\section{Results}

This section presents the results of the tests conducted to check whether male and female interpreters use the same strategies regarding connective markers. Table 2 shows the number of occurrences for each strategy and presented by gender.

Table 2. Strategies used by male and female interpreters when faced with connective markers

\begin{tabular}{|c|c|c|c|c|}
\hline Strategy used & Male interpreter & & $\begin{array}{l}\text { Female } \\
\text { interpreter }\end{array}$ & \\
\hline & $\begin{array}{l}\text { Absolute } \\
\text { numbers (\#) }\end{array}$ & $\begin{array}{l}\text { Normalized } \\
\text { frequencies } \\
(/ 1000)\end{array}$ & $\begin{array}{l}\text { Absolute } \\
\text { numbers (\#) }\end{array}$ & $\begin{array}{l}\text { Normalized } \\
\text { frequencies } \\
(/ 1000)\end{array}$ \\
\hline $\begin{array}{l}\text { In-group } \\
\text { equivalent }\end{array}$ & 81 & 4.01 & 166 & 4.79 \\
\hline $\begin{array}{l}\text { Equivalent in } \\
\text { source }\end{array}$ & 14 & 0.69 & 26 & 0.75 \\
\hline $\begin{array}{l}\text { Non-equivalent } \\
\text { in source }\end{array}$ & 9 & 0.45 & 17 & 0.49 \\
\hline Addition & 81 & 4.01 & 108 & 3.12 \\
\hline $\begin{array}{l}\text { Equivalent in } \\
\text { target }\end{array}$ & 3 & 0.15 & 5 & 0.14 \\
\hline $\begin{array}{l}\text { Non-equivalent } \\
\text { in target }\end{array}$ & 20 & 0.99 & 19 & 0.55 \\
\hline Omission & 59 & 2.92 & 82 & 2.37 \\
\hline Total & 267 & 13.22 & 423 & 12.21 \\
\hline
\end{tabular}


In absolute frequencies, female interpreters omit, add and 'translate' more connective markers than male interpreters do, except for the category 'noequivalent in target'. This is probably due to the fact that they are also faced with more markers. Further analysis of the normalized frequencies reveals that male interpreters omit and add slightly more connective markers than female interpreters. They also produce slightly more (non-)equivalents in target than their female colleagues, who tend to produce slightly more connective markers which fall into the categories in-group equivalents and (non-)equivalents in source. If we conduct a chi-square test for each strategy, we do not observe any statistical difference for in-group equivalents $(X=1.73 ; \mathrm{df}=2 ; \mathrm{p}>0.18)$, 'equivalents in source' $(\mathrm{X}=0.81 ; \mathrm{df}=2 ; \mathrm{p}>0.81)$, 'non-equivalents in source' $(\mathrm{X}=0.82 ; \mathrm{df}=2 ; \mathrm{p}>0.82)$, additions $(\mathrm{X}=2.97 ; \mathrm{df}=2 ; \mathrm{p}>0.08)$, non-equivalents in target $(X=3.51 ; \mathrm{df}=2 ; \mathrm{p}>0.06)$, and omissions $(X=1.54 ; \mathrm{df}=2 ; \mathrm{p}>0.22)$. The number of occurrences in the category 'equivalents in target' is too small to allow us to conduct a chi-square test. It is quite unexpected that gender is not a significant factor, considering the aforementioned literature.

The frequencies were subsequently further analysed taking into account other potential parameters that may cause omissions and additions, as mentioned in section 2. A multinomial regression was applied to sort out which parameters were significant. The statistical model fits the data moderately well: significance is not reached, but the model comes close: likelihood $=385.106 ; \mathrm{X}$ $=41.865 ; \mathrm{df}=30 ; \mathrm{p}=0.07$. Table 3 shows the results of the multinomial regression.

Table 3. Multinomial regression including four parameters

\begin{tabular}{|l|l|l|l|}
\hline Parameter & Chi-square & DF & P-value \\
\hline Interpreter's gender & 7.22 & 6 & 0.30 \\
\hline Language & 5.47 & 6 & 0.49 \\
\hline Speaker's gender & 5.91 & 6 & 0.43 \\
\hline Delivery rate & 22.75 & 12 & 0.03 \\
\hline
\end{tabular}

The multinomial regression test shows that the interpreter's gender is not significant, which confirms the results of the chi-square test. For the other parameters under study, the test yields the following results: language is not significant - which is quite unexpected considering the results of the other studies conducted in the field (Magnifico \& Defrancq, 2016, 2017, 2019) - nor is the speaker's gender. Finally, speech delivery rate is, on the other, a significant factor and that is in line with what we expected (Gerver, 1969).

We also conducted a test with 4 categories (correct rendition - incorrect rendition - addition - omission) but that model appeared to only have a slightly better fit (0.03 instead 0.07$)$ while yielding very similar results, without any significant change.

\section{Discussion}

With this study, we intended to explore a possible gender-based approach of norms in interpreting. Norms in interpreting have been mainly studied through extratextual and textual approaches, but most of the previous textual studies 
were based on a fairly small sample of textual material. Only a few studies are corpus-based, drawing in other words on a larger number of transcribed speeches and their interpretation, and are therefore suitable to conduct largescale statistical tests, which in turn, can help to reveal patterns. In this regard, we looked for textual items which would allow us to study norms in interpreting, and decided to opt for connective markers.

With our main research question, we set out to explore whether male and female interpreters have a different approach when dealing with connective markers. In this respect, the analysis did not yield any significant results in the use of the different strategies - in-group equivalent, equivalent in source, nonequivalent in source, addition, equivalent in target, non-equivalent in target, and omission - by male and female interpreters. It appears that the gender of the interpreter is not a significant factor for the strategy used by the interpreter when $\mathrm{s} / \mathrm{he}$ is faced with connective markers. This lack of significance is quite striking as the study conducted by Mason (2008) revealed a gender dimension in the handling of discourse markers. On the other hand, connective markers are often considered vulnerable items, which are prone to be among the first elements to be omitted when the interpreter is faced with cognitive overload (Hale, 2004; Mason, 2008). Barik (1971, p. 202) even considers the omission of pragmatic markers, among which connective markers and fillers, as not disruptive and acceptable within the context of interpretation. We believe that the cognitive overload, which might be influenced by the speech delivery rate of the speech, could explain the lack of difference in the handling of connective markers. In that case, the results yielded by the present study are more in line with those found for sex differences in interpreting where no cognitive differences were found between male and female interpreters on various aspects, such as rendition of numbers, disfluencies and extrapolation, i.e. the number of elements placed after the verb in German and Dutch subclauses to decrease the interpreter's cognitive load (Collard, 2019).

If we compare the results yielded by this study with those obtained by the other corpus-based studies conducted on gender differences in interpreting (Magnifico \& Defrancq, 2016, 2017, 2019), it is very striking, however, that gender is not significant for connective markers. Gender differences were ascertained in the field of impoliteness as female interpreters translated more unmitigated face-threatening acts than male interpreters (Magnifico \& Defrancq, 2016), as well as in the field of hedges - textual items close to connective markers - where female interpreters were found to outhedge male interpreters (Magnifico \& Defrancq, 2017). In a more recent study on norms in interpreting, which focuses on self-repairs, i.e. interpreters' correction of their output as the expression of the norm which they follow, female interpreters appear to produce more self-repairs than male interpreters, thereby showing more concern for the normative aspect of their output (Magnifico \& Defrancq, 2019). For this reason, the results of this particular study are quite unexpected, but might be explained by other factors.

With regard to the other parameters under study, namely the language, the speaker's gender and the speech delivery rate, only the last parameter is significant, especially in the category 'omission'. In other words, when the interpreter is faced with a higher speech delivery rates, $\mathrm{s} /$ he tends to omit more markers. This last result is in line with our expectations, and could explain the lack of significance of the other parameters. The assumption of speech delivery rate impacting interpreters' performances was already touched upon by Gerver (1969) who laid the 'manageable' speech delivery rate at 100-120 words per minute. Indeed, a slower delivery rate gives the interpreter more time to process the source speech and reduces the interpreter's efforts (Gile, 1995), allowing $\mathrm{him} / \mathrm{her}$ to translate more elements. Yet, this corpus-based study allows us to confirm that speech delivery rate is a significant factor on a larger-scale. In this respect, it would be worthwhile to conduct research on the impact of speech 
delivery rate on interpreters' work, especially within the framework of the European Parliament. Speeches held there are often delivered at a rate far above Gerver's 'manageable' 100-120 words per minute.

Our findings should be interpreted in the light of some limitations. Firstly, our results have to be understood within the size of our corpus. Although the corpus is quite large for an interpreting corpus, it remains too small to draw general conclusions. A larger corpus would allow for more representative results. Secondly, the corpus presents an imbalance between male and female interpreters. For this study, we drew on two sub-corpora: the French-Dutch subcorpus - comprising 19 speeches interpreted by men and 20 by women - and the French-English sub-corpus - with 16 speeches interpreted by men and 23 by women. The French-Dutch sub-corpus is fairly well-balanced, but we transcribed the English interpretations of the same French source speeches. It appears that more female interpreters were working in the English booth than in the Dutch booth during the speeches which we transcribed. We used normalized frequencies and chi-square tests for comparison's sake, but a larger corpus is needed to allow us to confirm or challenge our results on a broader scale. Finally, a corpus-based approach is interesting to yield general patterns, but it is only the first step to contribute to a better understanding of a gendered normative behaviour in simultaneous interpreting. Indeed, such an approach does not allow us to ask the interpreter why s/he has decided to implement a particular strategy or to follow a specific norm. In this respect, a qualitative study with a focus group is needed to better grasp the interpreters' decision process.

\section{Conclusion}

The present paper studied possible gender differences towards norms in simultaneous interpreting. Considering that the literature adduces a genderbased treatment of norms, a trend confirmed by a previous corpus-based study on norms (Magnifico \& Defrancq, 2019), it was assumed that these differences would be reflected in male and female interpreters' output. We reviewed the literature presenting the different norms at work in interpreting and operationalised them for a corpus-based study. In this regard, we chose to compare source and target texts to determine the interpreters' handling of connective markers and examine whether the strategies implemented would differ.

We based our study on the EPICG, which did not allow us to confirm our main hypothesis: it appears that male and female interpreters do not use different strategies when faced with connective markers. We also took into account other parameters which could influence the results: the language, the speaker's gender, and the speech delivery rate. It appeared that only the speech delivery rate seems be a significant factor, especially in the category 'omission'. This result is particularly interesting as interpreters in the European Parliament are often faced with high speech delivery rates. The impact of such a speech delivery rate on the interpreter's performance has already been touched upon by other researchers, such as Gerver (1969), but has never been explored on a large scale. With this corpus-based study, we could confirm that speech delivery rate affects interpreters' handling of connective markers. It would be worthwhile to further explore the impact of this parameter on the previous work about gender differences in interpreting.

In conclusion, this paper has given new insight on norms in interpreting, a field which remains not well researched. In contrast to previous studies, we could not confirm that male and female interpreters follow different norms, as they seem to handle connective markers in the same way. In order to maintain cohesion with our previous studies, we classified the gender groups under study 
according to the interpreter's sex. In the light of more recent developments in the field of gender studies, we realize that it could be worthwhile to explore possible differences within each gender group in the future. With this study, we also discovered incidentally that speech delivery rate influences interpreters' rendition strategies. Considering that the European Parliament is a place where speeches are often delivery at a rate far above the 'manageable' speed, it could be interesting to conduct a broader study on the effects of speech delivery rate on the interpreter's performances.

\section{References}

Angelelli, C. V. (2004). Revisiting the interpreter's role: a study of conference, court, and medical interpreters in Canada, Mexico, and the United States. Amsterdam: John Benjamins.

Bachy, S., Dister, A., Francard, M., Geron, G., Giroul, V., Hambye, P., Simon, A.-C. \& Wilmet, R. (2007). Conventions de transcription régissant les corpus de la banque de données VALIBEL. Retrieved from https://www.uclouvain.be/cps/ucl/doc/ valibel/documents/conventions_valibel_2004.PDF (October 15, 2013)

Baker, M. (1993). Corpus linguistics and translation studies: implications and applications. In M. Baker, G. Francis \& E. Tognini-Bonelli (Eds), Text and technology: in honour of John Sinclair (pp. 233-250). Amsterdam: John Benjamins.

Barik, H. (1971). A description of various types of omissions, additions and errors of translation encountered in simultaneous interpretation'. Meta, 16(4), 199-210.

Becher, V. (2010). Abandoning the notion of translation-inherent explicitation: Against a dogma of translation studies. Across Languages and Cultures, 11(1), 1-25.

Bergvall, V., Bing, J. \& Freed, A. (1996). Rethinking language and gender research: Theory and practice. New York: Addison Wesley Longman.

Bergvall, V., Bing, J. \& Freed, A. (2011). Rethinking language and gender research: Theory and practice. In R. Wodak, B. Johnstone, \& P. E. Kerswill (Eds.), The Sage handbook of sociolinguistics (pp. 411-423). London: Sage.

Brody, L.R., \& Hall, J.A. (1993). Gender and emotion. In M. Lewis, \& J.M. Haviland (Eds), Handbook of emotions (pp. 447-460). New York: Guiford Press.

Bühler, H. (1986). Linguistic (semantic) and extra-linguistic (pragmatic) criteria for the evaluation of conference interpretation and interpreters. Multilingua, 5(4), 231235.

Coates, J. (1993). Women, men and language ( $2^{\text {nd }}$ ed.). London: Longman.

Coates, J. (1996). You know so I mean probably: Hedges and hedging. In: Coates, J. (Ed.), Women talk: Conversation between women friends (pp. 152-173). Oxford: Blackwell.

Collados Aís, Á., Iglesias Fernández, E. P. M. E. M., \& Stévaux, E. (2011). Qualitätsparameter beim Simultandolmetschen. Interdisziplinäre Perspektiven. Tubinga: Gunter Narr.

Collard, C. (2019). A corpus-based study of simultaneous interpreting with special reference to sex ( $\mathrm{PhD}$ thesis). Ghent University. Faculty of Arts and Philosophy, Ghent, Belgium.

Defrancq, B., Plevoets, K., \& Magnifico, C. (2015). Connective markers in interpreting and translation: where do they come from. In J. Romero Trillo (Ed.), Corpus pragmatics in translation and contrastive studies, 3 (pp. 195-222). Dordrecht: Springer.

Dimitrova, B. E. (2005). Expertise and explicitation in the translation process. Amsterdam/Philadelphia: John Benjamins.

Diriker, E. (2004). De-/re-contextualizing conference interpreting: Interpreters in the ivory tower? Amsterdam: John Benjamins.

Duflou, V. (2016). Be(com)ing a conference interpreter: An ethnography of EU interpreters as a professional community. Amsterdam: John Benjamins.

Eckert, P. \& McConnell-Ginet, S. (2003). Language and Gender. Cambridge: Cambridge University Press.

Garzone, G. (2002). Quality and norms in interpretation. In G. Garzone \& M. Viezzi (Eds.), Interpreting in the $21^{\text {st }}$ Century: Challenges and opportunities (pp. 121130). Amsterdam: John Benjamins. 
Gerver, D. (1969). The effects of source language presentation rate on the performance of simultaneous conference interpreters. In E. Foulke (Ed.), Proceedings of the Second Louisville Conference on Rate and/or Frequency Controlled Speech (pp. 162-184). Louisville: University of Louisville.

Gile, D. (1995). Basic concepts and models for interpreter and translator training. Amsterdam: John Benjamins.

Hale, S. (2004). The discourse of court interpreting. Amsterdam: John Benjamins.

Harris, B. (1990). Norms in interpretation. Target, 2, 115-19.

Holmes, J. (1995). Women, men and politeness. London: Longman.

Jansen, P. (1992). The role of the interpreter in Dutch courtroom interaction: The impact of the situation on translational norms. In P. Jansen (Ed.), Selected papers of the CERA Research Seminars in Translation Studies 1992-1993 (pp. 133-155). Leuven: Katholieke Universiteit Leuven.

Kopczynski, A. (1994). Quality in conference interpreting: Some pragmatic problems. In M. Snell-Hornby, F. Pöchhacker \& K. Kaindl (Eds.), Translation Studies. An interdiscipline (pp. 189-198). Amsterdam: John Benjamins.

Labov, W. (1966). The social stratification of English in New York City. Washington DC: Center for Applied Linguistics.

Labov, W. (2001). Principles of linguistic change. 2: Social factors. Oxford: Blackwell.

Lakoff, R. (1975). Language and woman's place. New York: Harper Colophon.

Lederer, M. (1981). La traduction simultanée - Fondements théoriques. Paris: Minard Lettres Modernes.

Magnifico, C. \& Defrancq, B. (2016). Impoliteness in interpreting: a question of gender? Translation \& Interpreting, 8(2), 26-45.

Magnifico, C., \& Defrancq, B. (2017). Hedges in conference interpreting: The role of gender. Interpreting, 19(1), 21-46.

Magnifico, C., \& Defrancq, B. (2019). Self-repair as a norm-related strategy in simultaneous interpreting and its implications for gendered approaches to interpreting. Target, 31(3), 352-377.

Mason, M. (2008). Courtroom interpreting. Lanham: University Press of America.

Mauranen, A. (2000). Strange strings in translated language: A study on corpora. In M. Olohan (Ed.), Intercultural faultines. Research models in translation studies 1: Textual and cognitive aspects (pp. 119-141). Manchester: St. Jerome Publishing.

Mills, S. (2003). Gender and politeness. Cambridge: Cambridge University Press.

Monacelli, C. (2009). Self-preservation in simultaneous interpreting. Amsterdam: John Benjamins.

Moser, P. (1995). Simultanes Konferenzdolmetschen. Anforderungen und Erwartungen der Benutzer. Endbericht im Auftrag von AIIC. Vienna: SRZ Stadt und Regionalforschung GmbH.

Moser, P. (1996). Expectations of users of Conference Interpretation. Interpreting, 1/2, $145-178$

$\mathrm{Ng}$, B. C. (1992). End users' subjective reaction to the performance of student interpreters. The Interpreters' Newsletter, special issue, 1, 35-41.

Olohan, M., \& Baker, M. (2000). Reporting that in translated English. Evidence for subconscious processes of explicitation? Across Languages and Cultures, 1(2), $141-158$.

Pöchhacker, F. (1995). Simultaneous interpreting: A functionalist perspective. Hermes. Journal of Linguistics, 14, 31-53.

Pöchhacker, F., \& Zwischenberger, C. (2010). Survey on quality and role: conference interpreters' expectations and self-perceptions. Retrieved from http://aiic.net/p/ 3405 (October 14, 2017).

Puurtinen, T. (2004). Explicitations of clausal relations. A corpus-based analysis of clause connectives in translated and non-translated Finnish children's literature. In A. Mauranen \& P. Kujamäki (Eds.), Translation universals: Do they exist? (pp. 65-82). Amsterdam: Benjamins.

Saldanha, G. (2008). Explicitation revisited: Bringing the reader into the picture. Transkom, 1(1), 20-35.

Sánchez-Núñez, M. T., Fernández-Berrocal, P., Montañes, J., \& Latorre, J.M. (2008). Does emotional intelligence depend on gender? The socialization of emotional competencies in men and women and its implications. Electronic Journal of Research in Educational Psychology, 15(6), 455-474. 
Schjoldager, A. (1995). An exploratory study of translational norms in simultaneous interpreting: Methodological reflections. Hermes, Journal of Linguistics, 14, 65 87.

Seleskovitch, D. (1975). Langage, langues et mémoire: Étude de la prise de notes en interprétation consécutive. Paris: Minard Lettres Modernes.

Shlesinger, M. (1989). Extending the theory of translation to interpretation: Norms as a case in point. Target, 1(1), 111-115.

Shlesinger, M. (1995). Shifts in cohesion in simultaneous interpreting. The Translator, $1(2), 193-214$

Toury, G. (1980). In search of a theory of translation. Tel Aviv: The Porter Institute.

Toury, G. (1995). Descriptive Translation Studies and beyond. Amsterdam: John Benjamins.

Trudgill, P. (1972). Sex, covert prestige and linguistic change in the urban British English of Norwich. Language in Society, 1, 179-195.

Vandepitte, S., Denturck, K., \& Willems, D. (2013). Translator respect for source text information structure: A parallel investigation of causal connectors. Across Languages and Cultures, 14(1), 47-73.

Wadensjö, C. (1992). Interpreting as interaction: On dialogue interpreting in immigration hearings and medical encounters ( $\mathrm{PhD}$ thesis). University of Linköping.

Zwischenberger, C. (2009). Conference interpreters and their self-representation: A worldwide web-based survey. Translation and Interpreting Studies, 4(2), 239253. 